\title{
Garden pea (Pisum sativum L.) in Russian folk culture
}

\author{
Andrey Sinjushin
}

M. V. Lomonosov Moscow State University, Biological Faculty, Genetics Department, GSP-1, Leninskie Gory, Moscow, 119234, Russian Federation

\begin{abstract}
Summary: This paper aims to briefly review how a garden pea (Pisum satizum L.) is imprinted in the folk culture of Russian-speaking territories. Having been the most important legume of this territory for millennia, this plant left its traces in local and personal names, proverbs and idioms. Some of these pieces of folklore may help to reconstruct the phenotype of peas cultivated in the old Russia.

Key words: folklore, linguistics, Pisum sativum, Russia, traditional agriculture
\end{abstract}

\section{Introduction}

Agricultural plant biology fuses together various activities, such as studies of genetic control of preferred characteristics and investigation of physiological responses to environmental influences. Some interesting aspects arise where plant biology meets humanitarian questions, such as anthropology, archaeology, sociology, and linguistics. As a result of these diverse studies, plant biologists discover how, when and where certain crops were domesticated, or how crop names in different languages reflect patterns of a crop's distribution.

A garden pea (Pisum sativum L.: Fabaceae) was one of the earliest cultivated in Europe, as its remnants have been found in numerous sites since the early Neolithic period (reviewed by Ljuština \& Mikić, 2010). During the early Iron Age, a territory of contemporary European Russia (including Moscow) was populated by the Finno-Ugrians who were associated with the so-called Dyakovo archeological culture (7th $\mathrm{BC}-5$ th $\mathrm{AD}$ ). These tribes were succeeded (or assimilated) by Slavic people.

Corresponding author

asinjushin@mail.ru

Acknowledgement:

I would like to dedicate this work (which was not intended as an exhaustive academic investigation on a topic) to Dr Aleksandar Mikić, an engrained dreamer and tireless worker, a founder of linguoleguministics and good friend and colleague of many of legume researchers wotldwide. I hope all these who know Dr Mikic will join me wishing him strength and persistence in all his activities and inspirations. 1 express my sincere gratitude to Dr Noel Fillis and Dr Julie Hofer for language cotrection and helpful comments on the manuscript, as well as to an anonymous reviewer for nseful criticism. Many thanks to Margatita Markova for assistance with preparation of map (Fig. 1).

Cite this article:

Sinjushin A. (2019). Garden pea (Pzrm satum L.) in Russian folk culture. Ratan Pout, 56 (2), 65-70.
Excavations of numerous archeological sites of the Dyakovo culture indicate that pea was cultivated there together with some cereals (Gorbanenko, 2015).

To date, pea remains one of the most important leguminous crops of the Russian Federation. According to FAO data, ca. 3.27 million tons of dry peas were produced in Russia in 2017 (FAO, 2019). Hence, peas are second only to a soybean ( 3.62 million tons in 2017 ) in production volume. Moreover, in 2017 Russia was the second largest producer of dry peas in the world (FAO, 2019).

This paper aims to elucidate briefly the imprints left on Russian folklore by the centuries-long cultivation of garden pea. The importance of peas in Russian agriculture explains why peas featured in the everyday life of Russians for centuries, and are reflected in folklore, geographical names, traditions and customs, some of which still can be traced.

\section{Toponyms (place names)}

Having been the most important legume crop of the USSR, former Russian Empire, Medieval Russia (and earlier), i.e. on a large area inhabited mostly by Russian speakers, pea is imprinted in numerous names of villages, farms, rivers, lakes, and islands (Fig. 1). On the map of the contemporary Russian Federation, there are more than 40 settlements with names clearly derived from ropox (gońkh: "pea"). The most popular names are Gorokhovo (19) and Gorokhovka (11). Similar names can be found on maps of Ukraine and Belarus.

Numerous hydronyms also possess pea-related names. These are small rivers Gorokhovka (at least six), Gorokhovaya (three), Goroshek etc., lakes Gorokhovskoye and Gorokhovoye. Vladimir Dahl (1882), one of the most authoritative Russian lexicographers, listed dialect words burchug and burchak to denote some varieties of pea. The 


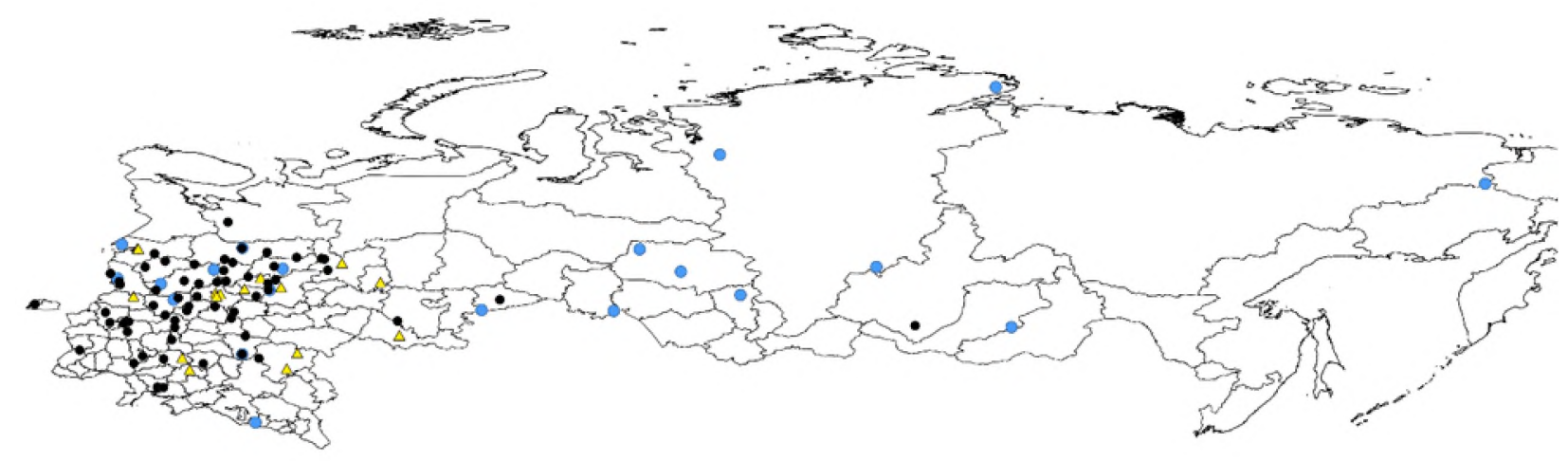

Figure 1. Distribution of pea-related toponyms in Russia (the part of Far East is not shown), Ukraine and Belarus. Black circles = names of settlements; blue circles = hydronyms; yellow triangles = street names. Map data were extracted from the GADM database, version 3.4 .

first of them, burchug, was recorded in what is now southern Ukraine, while the other word, burchak, existed in the North-Westem Russian Empire (a part now belonging mostly to Belarus). In both regions, there are a few toponyms (villages, river) with the names Burchak. These words are seemingly related to burkak denoting pea in most modern Turkic languages (Mikić \& Perić, 2011).

The resulting map (Fig. 1) is not fully exhaustive. Many settlements became desolated during the 20th century, so the list under discussion is based only on web-searchable sources and does not consider those localities of the former Russian Empire which do not exist anymore.

In addition to names of rural localities, there is a town named Gorokhovéts in the Vladimir Region. It has been known by this name at least since 1239 when it was mentioned in chronicles as burned by Mongol invaders. However, the author of the chronicles mentions it as a grad, i.e. a fortress or town, so the settlement with this name might have existed long before 1239. In 1781, the Empress Catherine II granted a coat of arms to this town. Its description states, "on a golden field, there is a pea growing on black poles denoting a name of this town" (Description, 1830). In its initial form, the coat of arms depicted eleven poles entwined with peas while the contemporary version contains images of five such poles (Fig. 2). It is possibly the only officially-recognized coat of arms bearing an image of peas.

The distribution of pea-related toponyms on the map of Russia and neighboring countries generally corresponds to areas that have been under pea cultivation for centuries (Fig. 1) and which remain so to date. Both Eastern and Western Siberia, as well as the Russian Far East, are much less suitable for cultivating peas, as compared with European Russia. Out of 136 cultivars of grain pea officially admitted for usage in Russia, only 37 are recommended for planting in Siberia or the Far East (State Register, 2018).

In both historical capitals of Russia, Moscow and Saint Petersburg, there are city toponyms (urbanonyms) connected with pea. One of the central streets of Saint Petersburg is Gorokhovaya Street, which was named in the 1770s. Local history states that this name was acquired after a foreigner (possibly a merchant) named Harrach built his house on this street in the $1750 \mathrm{~s}$. Russian citizens phonically adopted the name of this foreigner as "Gorokh", and later transferred this to the whole street (Gorbachevich \& Khablo, 2002). However, one cannot exclude the possibility that this is a kind of an "urban myth", and that the actual derivation of the name comes from its former use in the production, storage or marketing of peas (Broytman, 2010).

A street with the same name (Gorokhovaya or Gorokhovskaya) existed in Moscow but was renamed in 1939. This urbanonym appeared at the beginning of 18th century in its initial form "Gorókhovoye póle", i.e.

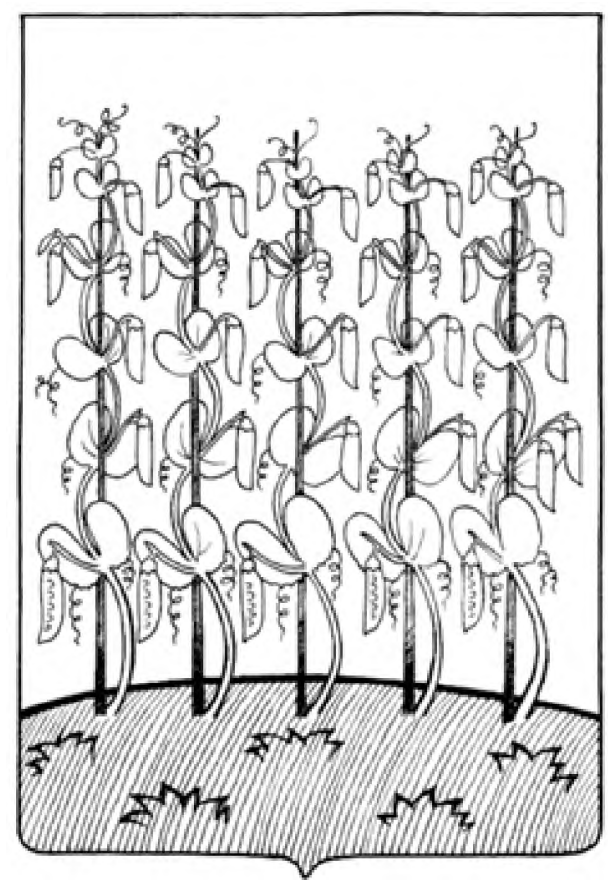

Figure 2. A coat of arms of Gorokhovets (author's drawing) 
"field of pea", as this place was utilized for growing peas for the royal court of Russia. This fact is also fixed in the historical names of Gorokhovskii lane and the church of the Ascension of Christ "na Gorokhowom pole", both situated near the former Gorokhovskaya street (Sytin, 1958). The pea-related names of streets or lanes can be found in a few other Russian cities and towns (Kirov, Volgograd, Kamyshin, Orenburg, Vichuga etc.), although the origin of these names needs further investigation.

\section{Anthroponyms (personal names)}

In Novgorod in 1582, three children of landlord Andrey Semichev were listed as Pedzka (Réd'ka. "Raddish"), Kanycma (Kapuista. "Cabbage") and Гopox (Gorókb: "Pea") (Nikonov, 1993). This seems the earliest known record of a pea-related (nick)name. Pea-related surnames have been documented since the 16th century, such as Goroshko (1581) and Gorokh (1585) (Tupikov, 1903). For comparison, in Belarus the first pea-related family name Goroshko was mentioned in 1746 (Biryla, 1960).

In contemporary Russia, the family name Gorkhow is listed among the 500 most widespread (Zhuravlev, 2005), suggesting a wide distribution of the corresponding nickname Gorokh. Ivanov is the most common surname in
Russia, and a frequency of Gorokbov is about $3 \%$ of the one of Ivanow (Zhuravlev, 2005).

\section{Folklore}

Garden pea is mentioned in numerous pieces of Russian folklore, such as proverbs, fairy tales, nursery rhymes, folk calendars, etc. In many Russian fairy tales, a traditional introduction (such as "once upon a time" or "when God's dog was a puppy") is npu uape Гopoxe (pri tsaré Gorkkbe: "under the rule of Tsar Gorokh" Fig. 3C). Beyond fairy tales, this idiom means "long ago" (Zhuravlev, 2010). Sometimes this introductory construction is extended, as in npu uape Topoxe u uapuue Yevebuue (pri tsaré Gorokhe i tsaritse Chechevitse: "under the rule of Tsar Gorokh and Tsarina Lentil').

Another mythical character closely associated with peas is the warrior Покаmuropouex (Pokatigoroshek: "Roll-a-pea"). In a set of Russian, Ukrainian and Belarussian fairy tales, he defeats a dragon with his cudgel and frees his siblings. This name was given to him because his mother became pregnant as a result of eating a pea seed (Pomerantseva \& Chistov, 1984). Interestingly, in some dialects, the idiom "she ate too much peas" served as euphemism for pregnancy, especially unexpected (Bunchuk, 2012a). This example, together with others, led Bunchuk (2012a) to suggest that pea may have generalized erotic connotations in Russian folklore.

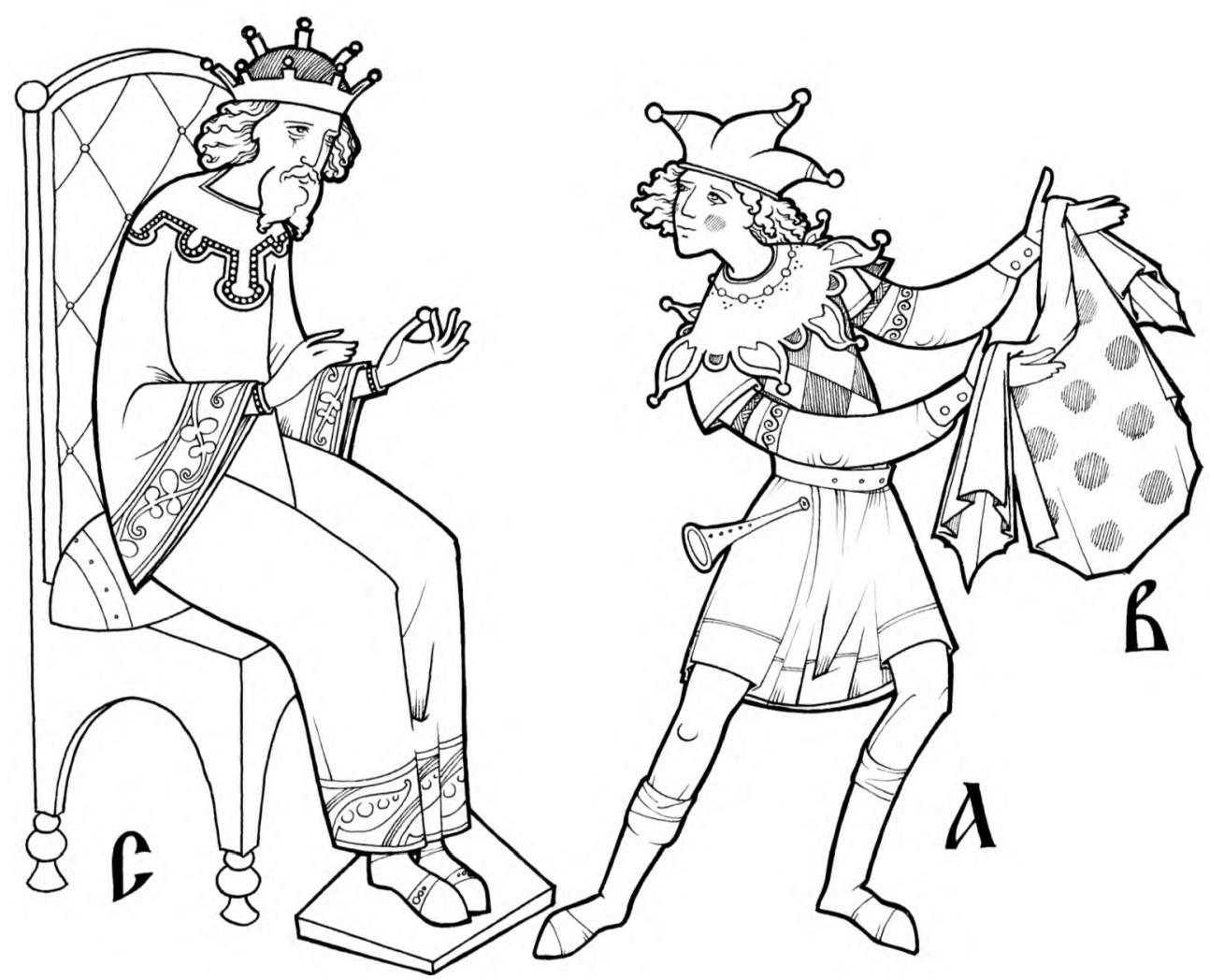

Figure 3. Author's vision of shut gorokhovyi (A) displaying a sample of textile with $\nu$ goroshek color pattern (B) to Tsar Gorokh (C). 
The Russian language still uses a comparative idiom, uym ropoxоввий (shit gorókhoryi. "pea buffoon"), to denote somebody behaving in a strange and inadequate way (Fig. 3A). The exact origin of this idiom is obscure (Bunchuk, 2012b). Possibly it refers to a rattle, a bag filled with peas, or an inflated bladder containing peas used by a clown to hit people on the head. "Pea buffoon" might initially have meant a scarecrow, placed in a pea field to scare crows and other birds.

In his "Explanatory dictionary of the living great Russian language", Vladimir Dahl (1882) recorded a number of proverbs and other short phrases in folklore connected with pea. Some are especially interesting to plant biologists, as they shed some light on the phenotypes of peas grown in Russia centuries ago. Here are some examples, given in translation and with transliteration.

Каб̈в на горох не мороз, он баз и mзzн nерерос (Káby na gorókh ne moróz on by i tyn pererós: "If frost would not come, a pea might overgrow a fence") (Dahl, 1882). This proverb is describing pea plants that attain luxuriant, indeterminate growth, either late in summer, just before the frosts heralding the onset of winter, or, early in summer, having escaped spring frosts. In the latter case, these would be early flowering, spring pea varieties (Weller et al., 2012).

Малы малыиики катали катьиики, сквозь землю проиили,

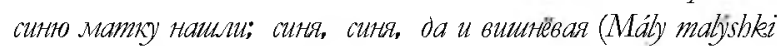
katäli katjishki, skvoq' rémlyu proshli, sinyu mátku nashli; sinja, simya, da i vishnyónaya. "Little moppets were rolling beads; they came through the ground and found mommy of blue and cherry color"). This quiz, although difficult for both translation and understanding even for contemporary Russian speakers, gives a clear impression of peas with pigmented flowers and rounded seeds.

In addition, many idioms mentioning pea have a connotation of something rolling, jumping or bouncing. For example, dypaka yum - umo в cmery гopox nenumb (duraká uchit' - chto $v$ stém gorókh lopit: "teaching a fool is like throwing peas at a wall"). Similarly, pacczinanca ropox na mвасячy (uеmuднаduamb) dopor (rassypalsya gorókh na týsyachu (chetymatsat") dorng. "peas rolled over thousands (or fourteen) of roads") is a folk metaphor for a night sky full of stars (or, more prosaically, for people going home after church) (Dahl, 1879, 1882).

Some pieces of folklore are clearly associated with the fact that pea was both widespread and very popular. There was a proverb горох в noле, чпо девка в доме: кmo нu npoùdëm. всак yuuntëm (gorókh v póle, chto dévka v dóme: kto ni proidyót, vsyak ushchipnyót. "a pea in a field is like a maid in a house: everybody passing by tries to pinch them") (Dahl, 1882).

\section{Folk calendar}

As elsewhere in Europe, every day of the old Russian calendar was attributed to a saint. However, dates connected with important stages of pea horticulture were also reflected in their names. In his "Proverbs of the Russian people", V. Dahl (1879) provided a folk calendar reflecting numerous agricultural habits and prescriptions. There are few dates (given according to the Gregorian calendar) recommended to sow peas. One such day, dedicated to St. Job (May 19), had a folk name of Hob Гopoutuk (Ióv Goróshnik, i.e. "Job the Peaperson"). It is seemingy the latest date. It was also said to sow "early" peas before the St. George's day (May 0) and "late" peas after this day. St. George was one of the most revered saints in Russia, so all agricultural works were prohibited on May 6. One of folk legends states that several countrymen were sowing peas on St. George's day, and a holy martyr himself dispersed seeds and threw a handful of peas to the sky. As a result, the Milky Way appeared to warn everybody from works on this fete (Dobrovol'skaya, 2010).

The earliest dates for sowing peas were Brazobemerue (Blagoveshcheniye: the Feast of the Annunciation, April 7) and 1azapeвa yóoma (Lágareva subbóta. the day before Palm Sunday). If the night before the Easter was starlight, a year was expected unfruitful for harvesting peas. Unfortunately, there is no attribution of region of the former Russian Empire where these recommendations were recorded. Possibly it is Ukraine or one of southernmost states, as in central European part of the contemporary Russia these days are usually cold.

Two dates are listed as recommended for harvesting peas in (Dahl, 1879), viz. Ильин deнь (Il'yín den': St. Elijah's day, August 2) and Пepвbrü Cnac (Péryyi Spas: the All-Merciful Savior's Day, August 14). Although it is difficult to reconstruct how different days of sowing peas were combined with days of harvesting, even the shortest vegetation interval (May 18 - August 2) comprised 76 days. The contemporary cultivars with similar vegetation period are classified as mid- or late-ripening (State Register, 2018).

\section{Miscellaneous facts}

Possibly the first written reference to pea in Russian literature is connected with the oldest Russian corpus of laws, "Русккая Правда" (Rússkaya Právda), in a part of it dated from the beginning of the 12 th century. According to this document, country people were obliged to feed an investigator, вирник (virnik), carrying out an investigation on criminal case in a given locality. Among numerous directives, seven yópkos (ubórkor: ancient measure of weight but of unknown value) of pea were prescribed to be given to an inspector every week (Grekov, 1947).

Pea is a component of very many Russian meals, although in present-day Russian cuisine, even so-called "traditional" dishes, pea has yielded somewhat to peregrine crops such as potato and buckwheat. In Medieval Russia dry pea was a traditional long-keeping 
food product available for unwealthy citizens and suitable for fasting days. The latter attribute was especially relevant in the climatic conditions of European Russia, as in those days there was no possibility of obtaining fresh vegetables or fruits during winter and spring, which are notable for their long canonical fasts, Advent and Great Lent. During fasting days, boiled and milled peas were used as a pie filler, porridges, mash, "cheese" made of pea puree with vegetable oil, broth, noodles etc. (Kostomarov, 1860). The oldest known recipe for pea (together with faba bean and lentil) is for comuso (sóchivo: coliphia, i.e. a ritual meal, often a funeral repast), which is found in the Kormchaia Book of Novgorod, a nomocanon dating from ca. 1280-1282 (Avanesov, 1989).

A verb ocopounms (ogoroshit: literally "to pea (somebody)") still exists in the Russian language and means "to shock" or "to confuse" (somebody). Its origin remains uncertain.

A color pattern "b ropoutek" (v goróshek) means polka dots, i.e. round spots in a contrasting colour (Fig. 3B).

Folk names of many wild-growing legumes reflect their similarity to garden pea. Some of them have entered academic botanical literature as the common names of certain plants. Examples are мъаиинъй гороиек (mysbinyi goróshek: "mouse pea") for Vicia cracca and забopнызіu гороiueк (zabormyi goróshek: "fence pea") for V. sepium. The genus Vicia is called goróshek in modern Russian, although with some exceptions (e.g. V.faba is called $606 \sigma z-b o b y$ ). In dialects, the word goróshek has been repeatedly attributed to different legumes (Comnilla, Astragalus etc.), while in contemporary Russian botanical nomenclature this name is used only for the genus Vicia except that Lathyrus odoratus is still called dyunicmoù гоpoutex (dushistyi goróshek: "fragrant pea"). This repeated attribution of the word "pea" is not unique to the Russian language but can be found in other European languages including English with its sweetpea, chickpea, pigeonpea etc.

Пlocmabums на горох (postavit' na gorokh: "to put (somebody) on a pea") means "to punish", especially in education-related circumstances. Nowadays it is used in a jocular manner but it reflects historical cases, when unsuccessful pupils were made to kneel on pulse seeds, such as pea, as a kind of strict punishment. For example, the anonymous merchant from the Perm region mentions this punishment in his memoirs, when describing his school education (ca. 1790) (Note, 1860).

\section{Conclusions}

Most ethnobotanical studies focus on the cultures of under-represented peoples, usually in tropical regions. However, even in European countries one may find many underexplored aspects of the ethnic usage of crops, which are traditionally received as ordinary, such as pea. In the course of urbanization, many of these diverse traditional usages are becoming irreparably lost. Although this problem is of less importance compared with food insecurity and the development of new varieties and technologies, these traditions are still worth studying, systematizing and maintaining. Traces of centuries-old rural agricultural practices and folk traditions add an important cultural perspective to plant science that is at risk of being ignored.

A brief review of pieces of folk culture of Russia (or, to be precise, Russian-speaking territories) connected with peas can help us to reconstruct the phenotype of pea cultivated in this region. This pea was similar to the wildgrowing peas, having (mostly) dominant traits. These are long indeterminate stem, pigmented flower, round seeds. Although peas were occasionally picked up ("pinched") unripe, there were no technologies for long preservation of vegetable peas, so it was used as a grain crop. There are no traces of using either early-flowering or wintering pea varieties.

\section{References}

Avanesov, R.I. (ed.) (1989) Dictionary of the Old Russian language of the 11 -14th centuries (In Russian), 2. Russkii Iazyk, Moscow.

Biryla, M.V. (1966). Belanussian antbroponymics (In Belarussian). Navuka i Tekhnika, Minsk.

Broytman, L.I. (2010). Gorokbovaya street (In Russian). Kriga, Saint Petersburg.

Bunchuk, T.N. (2012a). A pea in language and traditional culture of the Russian North (In Russian). Severnorusskiye Govoy (Northern Russian Dialects), 12, 117-133.

Bunchuk, T.N. (2012b). Pea buffoon (In Russian). Russkaya rech', 4, $119-124$.

Dahl, V.I. (1879). Proverbs of the Russian people (In Russian). Association of M.O. Wolf, Moscow \& Saint Petersburg.

Dahl, V.I. (1882). The explanatory dictionary of the living great Russian language (In Russian), 1: 381-382. Association of M.O. Wolf, Moscow \& Saint Petersburg.

Description of coat of arms for cities of Vladimir Region (1830). In: Complete compilation of laws of the Russian Empire (In Russian), 21, 218. Printing House of the 2nd Department of His Imperial Majesty's Chancellery, Saint Petersburg.

Dobrovol'skaya, V.E. (2010). Names for the Milky Way in traditional culture of the Vladimir Region (astronyms and associated myths). In: From Congress to Congress. The Materials of the 2nd AllRussian Congress of Folklorists (In Russian), 1, 145-157. State Republican Center of Russian Folklore, Moscow.

Food and Agriculture Organization of the United Nations (2019). FAOSTAT. Available at www.fao.org/faostat/en/. Accessed January 12, 2019.

Gorbachevich, KS., \& Khablo, Ye.P. (2002). Why so named? On the onigin of names of strets, squares, islands, vivers, and bridges of Saint Petersburg (In Russian). 5th ed. Norint, Saint Petersburg.

Gorbanenko, S. (2015). Palaeoethnobotanical materials from Znamenskoe hill-fort and Dyakovo culture grain production (In Russian, with English abstract). Tyragetia (s.n.), 9, 151-159.

Grekov, B. D. (ed.) (1947). Prawda Rzusskexya V. 2. Comments (In Russian) Publishing House of the Academy of Sciences of the USSR, Moscow \& Leningrad.

Kostomarov, I.I. (1860). The outtine of domesticity and babits of the Russian people in 16-17th centuries (In Russian). Publishing house of K. Wulf, Saint Petersburg. 
Ljuština, M., \& Mikić, A. (2010). A brief review on the early distribution of pea (Pisum sativum L.) in Europe. Ratarstio i Pontarstio, 47, 457-460.

Mikić, A., \& Perić, V. (2011). An etymological and lexicological note on the words for some ancient Eurasian grain legume crops in Turkic languages. Turkish Journal of Field Crops, 16, 179-182.

Nikonov, V.A. (1993). The dictionary of Russian family names (In Russian). Shkola-Press, Moscow.

Note found in archives of the late merchant S-v (1860). In: Perm Collected Volume (In Russian), 2 (supplement), xxvii-xxx. Printing House of Grachev \& Co., Moscow.

Pomerantseva, E. V., \& Chistov, K. V. (1984). Russian Fainy Tales of A. N. Afanasyey (In Russian), 1: 205-214. Nauka, Moscow.

State vegister for selection achievements admitted for usage (national list) (In Russian) (2018), 1. FGBNU Rosinformagrotekh, Moscow.
Sytin, P.V. (1958) Excenpts on the history of Moscow streets (In Russian). 3rd ed.: 693-696. Moskovskii rabochii, Moscow.

Tupikov, N.M. (1903). The dictionary of Old Russian personal names (In Russian). Printing House of I.N. Skorokhodov, Saint Petersburg.

Weller, J., Liew, L.C., Hecht, V.F.G., Rajandran, V., Laurie, R.E., Ridge, S., Wenden, B., Vander Schoor, J.K, Jaminon, O., Blassiau, C., Dalmais, M., Rameau, C., Bendahmane, A., Macknignt, R.C. \& Lejeune-Hénaut, I. (2012). A conserved molecular basis for photoperiod adaptation in two temperate legumes. Proc. Natl. Acad. Soi. USA, 109, 21158-21163.

Zhuravlev, A.F. (2005). On statistics of Russian family names. I. Voprosy onomastiki (Problems of Onomastics), 2, 126-146. In Russian.

Zhuravlev, A.F. (2010). Who is Tsar Gorokb? (In Russian). Russkaya Rech', 2, 111-116.

\section{Grašak (Pisum sativum L.) u ruskoj narodnoj tradiciji}

\section{Andrey Sinjushin}

Sažetak: Ovaj rad je imao za cilj da ukratko prikaže uticaj graška (Pisum sativum L.) na narodnu tradiciju na teritorijama na kojima se govori ruski jezik. Kako je milenijumima bio najvažnija leguminoza na tim teritorijama, grašak je ostavio trag u lokalnim i ličnim imenima, poslovicama i idiomima. Neki od ovih detalja iz narodne tradicije mogli bi pomoći u rekonstrukciji fenotipa graškova gajenih u staroj Rusiji.

Key words: folklor, lingvistika, Pisum sativum, Rusija, tradicionalna poljoprivreda 